Переверзєв Д.

Форми адміністративно-правової охорони прав дітей з інвалідністю

DOI:

УДК 342.951:342.72:351.74

\title{
Дмитро Переверзєв,
}

здобувач Науково-дослідного інституту

публічного права

ORCID: http://orcid.org/0000-0001-6867-5395

\section{ФОРМИ АДМІНІСТРАТИВНО-ПРАВОВОЇ ОХОРОНИ ПРАВ ДІТЕЙ 3 ІНВАЛІДНІСТЮ}

На основі аналізу чинного законодавства, міжнародних угод та думок вчених-адміністративістів досліджено питання форм реалізації адміністративно-правової охорони прав дітей з інвалідністю. Визначено, щзо адміністративно-правова охорона прав дітей з інвалідністю виступає засобом впливу публічної адміністрації на учасників суспільних відносин з метою усунення бар'єрів у суспільстві, шуо перешкоджають належній реалізациї прав та інтересів таких дітей. Вказано, що форми адміністративно-правової охорони прав дітей з інвалідністю охоплюють значне коло дій та заходів, щзо реалізуються публічною адміністрачією в напрямку охорони прав дітей з інвалідністю для уникнення їхньої дискримінаиї за ознакою інвалідності та безперешкодної інтеграції їх до суспільства. Формується твердження, щзо форми діяльності органів публічної адміністраиії у иій сфері є виявом здійснення ними виконавчо-розпорядчої діяльності та надання відповідних адміністративних послуг з метою попередження правопорушень у сфері прав, свобод та інтересів дітей з інвалідністю в процесі їхньої соціалізащії, а також застосування заходів адміністративного примусу до осіб, які допустили порушення прав таких учасників суспільних правовідносин.

Ключові слова: діти з інвалідністю, публічна адміністраџія, адміністративно-правова охорона, суспільні відносини, форми адміністративного управління.

\section{Переверзев Д.}

Формы административно-правовой охраны прав детей с инвалидностью

На основе анализа действующего законодательства, международных соглашений и мнений ученых административистов исследованы вопросы форм реализации административно-правовой охраны прав детей с инвалидностью. Определено, что административно-правовая охрана прав детей с инвалидностью выступает средством воздействия публичной администрации на участников общественньх отношений с целью устранения существующих в обществе барьеров, мешающих надлежащей реализации прав и интересов таких детей. Автором отмечается, что формы административно-правовой охраны прав детей с инвалидностью включают в себя значительный круг действий и мероприятий, реализуемых публичной администрацией в направлении охраны прав детей с инвалидностью во избежание их дискриминации по признаку инвалидности и беспрепятственной интеграции их в общество. Формируется утверждение, что формь деятельности органов публичной администрации в этой сфере являются проявлением осуществления ими исполнительно-распорядительной деятельности и предоставления соответствующих административных услуг с иелью предупреждения правонарушений в сфере прав, свобод и интересов детей с инвалидностью в прочессе их сочиализации а также применение мер административного принуждения к лицам, допустивщим нарушения прав таких участников общественных правоотношений.

Ключевые слова: дети с инвалидностью, публичная администраџия, административно-правовая охрана, общественные отношения, формы административного управления.

\section{Pereverziev D.}

Forms of administrative and legal protection of the rights of children with disabilities

The article, based on the analysis of current legislation, international agreements and opinions of administrative scientists, examines the issues of forms of implementation of administrative and legal protection of the rights of children with disabilities. It is argued that the use of the institution of administrative and legal protection of rights, will ensure the manifestation of the rule of law and the formation of public consciousness in relation to such a category of members of society as children with disabilities. Emphasis is placed on the fact that disability is an evolving concept and that disability is the result of interactions between people with disabilities and relative and environmental barriers that hinder their full and effective participation in life of society on an equal footing with others. It is determined that the administrative and legal protection of the rights of children with disabilities is a means of influencing the public administration on the participants of public relations in order to remove existing barriers in society that prevent the proper realization of the () дмитро переверзєв, 2020 
rights and interests of such children. The author notes that the forms of administrative and legal protection of the rights of children with disabilities include a significant range of actions and measures taken by the public administration to protect the rights of children with disabilities to avoid discrimination on the grounds of disability and their smooth integration into society. It is determined that actions and measures taken by public administration bodies to protect the rights of children with disabilities are implemented in the form of legal, law enforcement, and law enforcement functions. It is argued that the forms of activity of public administration bodies in this area are a manifestation of their executive and administrative activities and the provision of appropriate administrative services to prevent violations in the field of rights, freedoms and interests of children with disabilities in the process of their socialization. persons who have violated the rights of such participants in public relations.

Keywords: children with disabilities, public administration, administrative and legal protection, public relations, forms of administrative management.

Постановка проблеми. Ратифікувавши Конвенцію про права дитини від 20.11.1989 року [1] та Конвенцію про права осіб з інвалідністю від 13.12.2006 року [2] Україна визнала, що діти мають право на особливе піклування і допомогу, відповідно до Декларації прав дитини, прийнятої резолюцією 1386 (XIV) Генеральної Асамблеї ООН від 20 листопада 1959 року [3] дитина, внаслідок їі фізичної і розумової незрілості, потребує спеціальної охорони і піклування, у т. ч. належний правовий захист як до, так і після народження.

Реалізувати визначені зобов’язання мають органи публічної адміністрації шляхом застосування інституту адміністративно-правової охорони прав, що забезпечить вияв ознак правової держави та формування суспільної свідомості щодо такої категорії членів суспільства, як діти з інвалідністю.

Інвалідність як соціальне явище притаманна кожній державі. Через наявність проблем зі здоров’ям особи з інвалідністю потребують вжиття з боку державних та громадських інституцій спеціальних заходів, спрямованих на забезпечення їх повної та повноцінної участі в житті соціуму на рівні з іншими [4, с. 4].

Адміністративно-правова охорона прав дітей з інвалідністю має свої власні форми ії здійснення, які ми аналізуватимемо в цьому дослідженні.

Аналіз наукових досліджень та публікацій. Питанням дослідження прав та свобод осіб з інвалідністю, здійсненню їхнього правового захисту з боку органів публічної адміністрації присвячено праці таких науковців, як С. Ю. Соболь, М.В.Кравченко, Р. О. Павлюков, С. В. Пасічниченко, О. В. Паровишник, М. В. Чічкань та ін. Проте подальшого дослідження потребують форми адміністративно-правової охорони прав дітей з інвалідністю у процесі їхньої інтеграції до суспільства.

Метою дослідження $є$ визначення сутності форм адміністративно-правової охорони прав дітей 3 інвалідністю.

Виклад основного матеріалу дослідження. В Конвенції про права осіб з інвалідністю від 13.12.2006 року світова спільнота, в тому числі й Україна, визнали інвалідність - як поняття, яке еволюціонує, і що інвалідність є результатом взаємодії людей, які мають порушення здоров’я, і бар’єрів у відносинах та суспільстві, що перешкоджає їхній повній та ефективній участі в житті суспільства нарівні 3 іншими [2].

3 огляду на таке трактування поняття інвалідності варто зазначити, що органи публічної адміністрації мають забезпечити можливість реалізації адміністративно-правової охорони прав дітей з інвалідністю шляхом усунення бар’єрів у суспільстві, що перешкоджають належній реалізації прав та інтересів таких дітей.

Тому, на думку С. Ю. Соболя, діяльність держави щодо осіб з інвалідністю виявляється у створенні правових, економічних, соціально-побутових і соціально-психологічних умов для задоволення їхніх потреб у покращенні здоров’я, матеріальному забезпеченні, трудовій діяльності тощо [5, с. 237].

Для визначення сутності форм адміністративно-правової охорони прав, варто звернути увагу на зміст самого поняття «адміністративно-правова охорона».

Як зазначає О. М. Правоторова, адміністративно-правова охорона є такою, що деякою мірою пов'язана з охоронною функцією права, проте не тотожна їй, адже до предмета адміністративно-правової охорони належать питання попередження порушення права, а за класичним правилом охоронна функція права включається в дію вже після порушення певного нематеріального чи матеріального блага особи [6, c. 157].

Отже, адміністративно-правова охорона прав дітей з інвалідністю - $є$ інститутом адміністративного права, складовими елементами якого виступають однорідні норми цієї галузі, які направлено на попередження порушення прав, свобод та законних інтересів дітей з інвалідністю, що здійснюється органами 
Переверзєв Д.

Форми адміністративно-правової охорони прав дітей з інвалідністю

публічної адміністрації для забезпечення реалізації повного й рівного здійснення такими дітьми всіх прав людини й основоположних свобод, та заохочення до поваги притаманного їм достоїнства [7, с. 87].

Оскільки питання адміністративно-правової охорони прав дітей з інвалідністю регулюються державою на законодавчому рівні та передбачають створення умов для попередження порушення прав, свобод та інтересів, така діяльність має провадитись у певних правових формах, що безпосередньо сприяє процедурі належного здійснення такої охорони прав та інтересів.

За твердженням Є. Ю. Соболя, належне забезпечення прав і свобод осіб з інвалідністю, їхній обсяг і характер свідчить про високий рівень демократизації громадянського суспільства [8, с. 20].

Для визначення поняття форм адміністративно-правової охорони прав дітей з інвалідністю варто звернути увагу на загальне визначення поняття форм діяльності суб’єктів публічної адміністрації.

На думку Я. В. Лазура, форма управління - це зовнішній вияв конкретних дій, які здійснюють органи державної влади для реалізації поставлених перед ними завдань. Термін «форма» означає вид, будь-який зовнішній вияв певного змісту. Якщо функції управління розкривають основні напрями цілеспрямованого впливу суб'єктів управління на об'єкти управління, то форми управління - це шляхи здійснення такого цілеспрямованого впливу, тобто форми управління показують, як практично здійснюється управлінська діяльність [9, с. 249-250].

В. Галунько та В. Курило визначають, що під формами діяльності публічної адміністрації розуміють зовнішнє вираження однорідних за своїм характером і правовою природою груп адміністративних дій посадових осіб і органів публічної адміністрації, здійснене в межах режиму законності та компетентності для досягнення адміністративно-правової мети - публічного забезпечення прав і свобод людини і громадянина, нормального функціонування громадянського суспільства та держави [10, с. 225-226].

Аналізуючи праці та погляди науковців з досліджуваного питання, доходимо висновку, що поняття форм адміністративно-правової охорони прав дітей з інвалідністю охоплює значне коло дій та заходів, що реалізуються органами публічної адміністрації в напрямку охорони прав дітей з інвалідністю для уникнення їх дискримінації за ознакою інвалідності та безперешкодної інтеграції їх до суспільства.

Такі дії та заходи, що вчиняються публічною адміністрацією з метою охорони прав дітей з інвалідністю, реалізуються у формі правоустановчих, правозастосовчих і правоохоронних функцій. Так, реалізуючи правоустановчу функцію державний орган видає нормативні акти, якими встановлюються загальнообов'язкові правила регулювання суспільних відносини у сфері дотримання гарантованих дітям з інвалідністю прав у сфері охорони здоров'я, освіти, доступності інфраструктури, соціального захисту.

Реалізація правозастосовчої функції відбувається у формі надання адміністративних послуг. Саме завдяки такій формі адміністративно-правової охорони, дитина з інвалідністю має можливість реалізувати свої права через спеціально уповноважені органи публічної адміністрації в питаннях проведення реабілітації, соціального забезпечення, охорони здоров'я тощо.

Правоохоронна функція публічної адміністрації щодо прав дітей з інвалідністю може бути реалізована у сфері правової охорони та правового захисту. Проте поняття «охорона» $є$ значно ширшим за поняття «захист». Охорона прав дітей з інвалідністю охоплює правові засоби і підстави їх реалізації та попередження порушення, $\epsilon$ формою врегулювання відносин між такими дітьми та органами публічної адміністрації. Захист прав дітей з інвалідністю $є$ засобом імперативної реалізації охоронюваних прав таких суб’єктів публічних правовідносин [7, с. 87]. Тож у межах нашого дослідження увага акцентується на питаннях адміністративно-правової охорони прав дітей з інвалідністю, яка відбувається у формі запровадження інституту адміністративного примусу, який забезпечує утримання від протиправних дій та порушення учасниками суспільних відносин прав, свобод та інтересів дітей з інвалідністю.

Форми публічного адміністрування у сфері адміністративно-правової охорони прав дітей з інвалідністю мають відповідати таким вимогам:

- здійснюватись згідно із законністю;

- вчинятись в межах компетенції органу публічної адміністрації;

- сприяти реалізації прав і законних інтересів дітей з інвалідністю.

Форми адміністративно-правової охорони прав дітей з інвалідністю характеризуються такими ознаками:

1) є зовнішнім виявом функціонування публічної адміністрації;

2) витікають з компетенції публічної адміністрації;

3) є юридично закріпленими; 
4) форма діяльності обирається публічною адміністрацією залежно від мети для ефективної реалізації прав дітей з інвалідністю;

5) їх застосування, як правило, має певні правові наслідки.

Висновки. Таким чином, узагальнюючи погляди науковців на адміністративно-правову охорону прав дітей з інвалідністю, можна зробити висновок, що форми діяльності органів публічної адміністрації у цій сфері $\epsilon$ виявом здійснення ними виконавчо-розпорядчої діяльності та надання відповідних адміністративних послуг з метою попередження правопорушень у сфері прав, свобод та інтересів дітей з інвалідністю в процесі їхньої соціалізації, а також застосування заходів адміністративного примусу до осіб, які допустили порушення прав таких учасників суспільних правовідносин.

\section{Список використаних джерел}

1. Конвенція про права дитини від 20.11.1989 року. URL: https://zakon.rada.gov.ua/laws/show/995_021\#Text (дата звернення: 28.09.2020).

2. Конвенція про права осіб з інвалідністю від 13.12.2006 року. URL: https://zakon.rada.gov.ua/laws/ show/995_g71\#Text (дата звернення: 28.09.2020).

3. Декларація прав дитини від 20.11.1959 року. URL: https://zakon.rada.gov.ua/laws/show/995_384\#Text (дата звернення: 28.09.2020).

4. Про становище осіб з інвалідністю в Україні : Національна доповідь. Державна установа Науково-дослідний інститут соціально-трудових відносин. Міністерство соціальної політики України. Київ, 2013. 198 c.

5. Соболь Є. Ю. Загальні аспекти соціально-психологічної адаптації інвалідів у соціумі. Право і Безпека. 2012. № 5. C. 237-241. URL: http://nbuv.gov.ua/UJRN/Pib_2012_5_54 (дата звернення: 30.09.2020).

6. Правоторова О. М. Поняття та зміст адміністративно-правової охорони. Юридичний науковий електронний журнал. 2019. № 4. С. 154-158.

7. Переверзєв Д. М. Сутність адміністративно-правової охорони прав дітей з інвалідністю. Журнал східноєвропейського права. 2020. № 79. С. 84-88. URL: http://easternlaw.com.ua/wp-content/uploads/2020/08/ pereverziev_79.pdf (дата звернення: 02.10.2020).

8. Соболь С. Ю. Реалізація людиноцентристського підходу до захисту прав та свобод інвалідів. Митна справа. 2014. № 4 (2). C. 20-25. URL: http://nbuv.gov.ua/UJRN/Ms_2014_4\%282\%29 6. (дата звернення: 02.10.2020).

9. Лазур Я. В. Форми адміністративно-правового захисту прав і свобод громадян у сфері державного управління. Форум права. 2010. № 2. С. 249-253. URL: http://nbuv.gov.ua/UJRN/FP_index. (дата звернення: 02.10.2020).

10. Галунько В. В., Курило В. І., Короєд С. О. та ін. Адміністративне право України. Т. 1. Загальне адміністративне право : навчальний посібник. Херсон : Грінь Д.С., 2015. 272 с.

\section{References}

1. Konventsiia pro prava dytyny [Convention about the rights of the child] (1989, November 20). URL: https:// zakon.rada.gov.ua/laws/show/995_021\#Text [in Ukrainian].

2. Konventsiia pro prava osib $z$ invalidnistiu [Convention on the Rights of Persons with Disabilities] (2006, December 13). URL: https://zakon.rada.gov.ua/laws/show/995_g71\#Text [in Ukrainian].

3. Deklaratsiia prav dytyny [Declaration of the Rights of the Child] (1959 November 20). URL: https://zakon. rada.gov.ua/laws/show/995_384\#Text [in Ukrainian].

4. Pro stanovyshche osib z invalidnistiu v Ukraini : Natsionalna dopovid. (2013). [On the Situation of Persons with Disabilities in Ukraine: A National Report]. Derzhavna ustanova Naukovo-doslidnyi instytut sotsialnotrudovykh vidnosyn. Ministerstvo sotsialnoi polityky Ukrainy. Kyiv [in Ukrainian].

5. Sobol, Ye. Yu. (2012). Zahalni aspekty sotsialno-psykholohichnoi adaptatsii invalidiv u sotsiumi. Pravo i Bezpeka [General aspects of socio-psychological adaptation of disabled people in society]. Pravo i BezpekaLaw and Security, 5, 237-241. Retrieved from http://nbuv.gov.ua/UJRN/Pib_2012_5_54 [inUkrainian].

6. Pravotorova, O.M. (2019). Poniattia ta zmist administratyvno-pravovoi okhorony. Yurydychnyi naukovyi elektronnyi zhurnal [The concept and content of administrative and legal protection]. Yurydychnyi naukovyi elektronnyi zhurnal - Legal scientific electronic journal, 4, 154-158 [in Ukrainian].

7. Pereverziev, D.M. (2020). Sutnist administratyvno-pravovoi okhorony prav ditei z invalidnistiu. Zhurnal skhidnoievropeiskoho prava [The essence of administrative and legal protection of the rights of children with 
disabilities]. Zhurnal skhidnoievropeiskoho prava - Journal of Eastern European Law, 79, 84-88. Retrieved from http://easternlaw.com.ua/wp-content/uploads/2020/08/pereverziev_79.pdf [in Ukrainian].

8. Sobol ,Ye. Yu. (2014) Realizatsiia liudynotsentrystskoho pidkhodu do zakhystu prav ta svobod invalidiv [Implementation of a human-centered approach to the protection of the rights and freedoms of people with disabilities]. Mytna sprava - Customs business, 4 (2), 20-25. URL: http://nbuv.gov.ua/UJRN/ Ms_2014_4\%282\%296. [in Ukrainian].

9. Lazur, Ya. V.(2010) Formy administratyvno-pravovoho zakhystu prav i svobod hromadian u sferi derzhavnoho upravlinnia [Forms of administrative and legal protection of the rights and freedoms of citizens in the field of public administration]. Forum prava - Law Forum, 2, 249-253. URL: http://nbuv.gov.ua/UJRN/FP_index [in Ukrainian].

10. Halunko, V.V., Kurylo ,V.I., K'oroied Sk.O. et al (2015). Administratyvne pravo Ukrainy. T. 1. Zahalne administratyvne pravo: navchalnyi posibnyk. [Administrative law of Ukraine. Vol. 1. General administrative law: a textbook]. Kherson: Hrin D.S. [in Ukrainian].

Стаття надійшла до редакції 05.10.2020. 